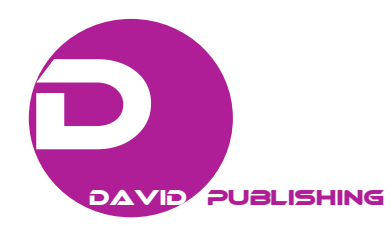

\title{
Place, Architecture Design and Thermal Comfort: A Municipal Day Care Childhood Center in Colônia Z3, Pelotas/RS, Brazil
}

\author{
Paulo A. Rheingantz ${ }^{1}$, Eduardo G. da Cunha ${ }^{2}$, Jaqueline da S. Peglow ${ }^{2}$, Viviane Ritter ${ }^{3}$, Luiza C. Quintana ${ }^{2}$, \\ Thalita dos S. Maciel $^{2}$, Carolina Beltrame ${ }^{2}$, Carolina de M. Duarte ${ }^{2}$ and Antonio C. B. da Silva ${ }^{2}$ \\ 1. Post-graduation Program in Architecture and Urbanism, Federal University of Pelotas, Pelotas, RS, 96010-020, Brazil; \\ 2. Department of Construction Technology, Federal University of Pelotas, Pelotas, RS, 96010-020, Brazil; \\ 3. Federal Institute Sul-rio-Grandense Campus Pelotas Visconde da Graça, Pelotas, RS 96010-020, Brazil
}

\begin{abstract}
This article reports the discussion about the multiple relations between architectural design and "place" using two different approaches in order to characterize the interfaces of design challenges. The first is qualitative, highlighting the lack of dialogue between the standard-project architecture, the guidelines recommended by the COEDI (Coordenação Geral de Educação Infantil (General Coordination of Early Childhood Education)) of the Ministry of Education, socio-technical and cultural-environmental context and pedagogy. The second, more quantitative, addresses the problems generated by dissociation between the constructive solutions and the bioclimatic demands of different insertion contexts of architectural design in the Brazilian Bioclimatic Zone 2. Initially planned to use a conventional building system, it was transposed to the Wall System, developed by MVC Componentes Plásticos Ltda. The simulation evaluates and compares the level of thermal comfort of the building with two envelope systems. The study reports the analysis of the thermal comfort of a Type C unit, based on thermodynamic simulation, through the software Design Builder (version 4.2.0.054). The analysis of the building simulation results was based on the adaptive comfort model ASHRAE 55/2010. Later, three optimization measures of the thermal comfort level of the building were tested, based on thermal insulation and absorptance coverage, in addition to sun protection system design for the window frames. Preliminary results for the level of comfort of long permanence environments indicate a low level of thermal comfort, the 50\% in MVC system and around $60 \%$ in the conventional system, and also that the greater discomfort comes from the heat. Based on performance optimization measures of building, the MVC system reached $66.4 \%$ of thermal comfort compared to $62 \%$ in the conventional system. The results show the importance of adapting the standard project to the local climatic context.
\end{abstract}

Key words: Place, architectural design, thermal comfort, energy modeling, child education.

\section{Introduction}

This paper starts from a research conducted at the Post-Graduation Program in Architecture and Urbanism at the Federal University of Pelotas (PROGRAU-UFPel), which is aligned with the STS (science-technology-society) studies and their questions about the universality of "scientific facts", which disconsiders the places or localities where

Corresponding author: Paulo A. Rheingantz, Ph.D., architect; research fields: architecture design, environmental perception, and post-occupancy evaluation. E-mail: parheingantz@gmail.com. knowledge is produced. It is also aligned with the STS assumption that ideas and discoveries are local or located and situated productions [1].

In this perspective, it is not possible to consider places and buildings, even though they are situated and located, as "fixed things of material nature" [2].

Even after they are built and occupied, places and buildings must dialogue and function together or in co-production with their "users" [3] and contexts. Since they must be recognized, equipped and host specific activities, their qualities do not pre-exist: they emerge from multiple association processes [4]. This 
way, buildings and places must be understood as "objects", whose specific duplicity makes them both singular - with a stable location and form - and able to host different activities relatively easily. Once they are "ready to be used" at the same time as they are "subject to future modifications", it is possible to qualify them as almost-technologies [5] or as unstable technologies, engaging "technical", "political" and "economic" entities which perform situated knowledge [1]. Places and buildings can be also recognized as a set of relationships between "users" that are human and non-human, which include values, sensations and conceptions related to the physical-formal features and to the activities and actions that are developed therein.

Thus, in this work, buildings and places are thought as interfaces or connections with their users and contexts and together with the movements and transformations produced from such connections. In the same line of reasoning, architecture project is understood as an ongoing process that does not have a definitive formulation, whose movements are permeated by circularity, instability and subjectivity. Its continuity does not end with the conclusion of projects or their construction and its quality comes from a collective effort that is complex, creative and strongly dependent of people, organizations and processes involved in its production and in its action or usage. Because it is inevitably and concomitantly a technical, social and aesthetical process, that is apparently engaged in a "technical" orthodoxy and in an "aesthetical" freedom, its quality is difficult to be explained, once it transcends technique and aesthetics, requiring knowledge that is different from most areas of expertise.

In this perspective and understanding architecture project as a continuous conception process that is inseparable from the intentions of the authors, whose common praxis paradoxically stabilizes uses and technologies and disregards an interpretative flexibility $[6,7]$, this article aims to: (1) explore possibilities and alternatives to improve the quality of the projects and the environment performance of the Municipal Day Care Childhood Center (EMEIs-initials from Brazilian denomination Escola Municipal de Educação Infantil, adopted to replace the world "creche", which carried a stigma because it referred to charity institutions) in the city of Pelotas, Brazil, emphasizing on those with the standard-project by the FNDE (Fundo Nacional de Desenvolvimento da Educação, National Fund for Education Development in English) for the Pro-Infância (Pro-Childhood) Program of the Ministry of Education. This program was created in 2007 , to provide financial assistance to municipalities, for building children's schools, with standardized architecture projects and financing for construction, furniture and equipment, as well as technical-pedagogical support and for new enrolments [6]; (2) contribute to overcoming: (a) limitation and inadequacy of an education concept that is not creative regarding spaces and climate [8]; and (b) a school architecture that does not question the relations between conception and organization of the environment, educational practices and today's social demands, producing schools that are almost identical through time and space [9].

Contradicting the recommendation that "the conception of the project must be preceded by participative process involving the educational community" from the reference document of the basic infrastructure guidelines for Day Care Childhood Centers [10], whose "goal is to achieve the accomplishment of the constitutional precept of administration decentralization, as well as participation of several social actors engaged in children education" (authors' translation) [10, 11], the pattern-designs for the EMEIs do not result from a dialogue with educators and children about the buildings where they will share their education experiences, nor from teaching-learning practices, dimensions, proximity or position of diverse environments, and even less from children's demonstrations in games, actions or talks 
about what they would like to have or to do in their school environments. They respond to the goals and objectives of the Pro-Infância Government Program, with projects conceived as closed packages with government prints or brand and despising the contextual differences and the cultural values of the communities. Important issues such as health and disposition of little children, educators and workers in their daily activities, environmental quality and thermal comfort were left to a secondary place.

Lastly, it is important to highlight that the structure and the content of the sections presented hereon do not follow an artificial compartmentation of contents into theoretical foundation, methodology and analysis. This option is grounded on the assumption that humans have a fundamental ability to gather what is apart $[10,11]$, or so to say, knowledge is built along the process or action of producing it [2, 12-15]. In this sense, it is about the dynamics of a progressive process of knowledge production by a body or "interface that learns" [16] whose mediation is sensitive to the differences that are produced and that is more easily described as one learns to be affected by other elements or actors. This option enables to outline what Whitehead called a "nature's bifurcation" [16], which separates the world and science, things and subjects and then stops "what things really are" [16]: a world of things-and-subjects.

\section{Considerations on the Conception of Buildings to Receive Early Childhood in Brazil}

Up to 1988, children education in Brazil has prioritized guarding children and most of the day care centers received poor children. Services were not worried about children's rights and most of the day care centers were adaptations of existing buildings, with poor infrastructure and habitability. They were some kind of "children warehouse". From 1988 on, children education becomes a state duty, access to education for all children from 0 to 6 years of age becomes a right and responsibility of municipalities.
However, the discussion about architecture for children education in Brazil is still limited to recognizing the importance of the pedagogical organization of the space [17], without exploring its potential as an interface for educational practices.

Instead of prioritizing children, pedagogical practices and the relationships that are produced in its environments, the "traditional" conception of architecture for children education prioritizes public policies and the agency of building designers and producers. Among architects, beyond the idea of rationality, economy and functionality, prevail the issues of organizing day care centers and what they offer to little children as if pedagogical practices and little children were all the same. They do not know that children need different times to learn and to relate; that they only take advantage on the situations if they are available and sensitive for it [17]. They also do not ask what pleases or interests children [18]. Even though they are physically present, little children are ignored, "made invisible" [19]. The adult-centered [20] or adult-morphic [20] point of view of those who design the EMEIs treats little children as incomplete or beings "to-be" [21], denying that little children are complete human beings. In order to break with such process, it is necessary that all those involved in children education learn to dialogue with little children as "subjects full of rights and with singular stories" [22], with the communities they come from and with those who educate them.

The organization of the day care center spaces strengthens the intention of control and surveillance over little children's actions [23], instead of playing a role of challenging and welcoming autonomy, freedom and the spirit of childhood. In this conception, still preponderates a logic of discipline, which keeps little children in an artificial immobility, which stops or makes it harder for them to interact. To make spaces challenging and welcoming, it is necessary to think the organization of day care childhood centers over. Since architects rarely speak to the education staff, there is no 
conversation between the architecture and pedagogical projects and its materiality is not connected to the educational management nor to the school ground [22]. In general, conversation is limited to make normative restrictions compatible with political interests and technical beliefs of those who design, supervise and keep EMEIs. Due to that, most of the public day care early childhood center designs become outdated devices, old-fashioned and maladjusted to the routine of little children education - pedagogical practices and contents, students' interests and demands. There is almost no space for the new or to question about possibilities or educational potentials of its materiality. The same happens regarding the subjectivities that emerge from the social-cultural-environmental diversity of schools and the urban sites where they are built. Since most of the decision-makers and the designers have never attended a day care centre, there are no reliable guidelines or models of support environments for little children out of their houses [24]. With that, the "a priori" conception of buildings and environments to receive little children is a projection of their authors' dreams and fantasies, and not those of the children they are designed for [25].

\section{Considerations about the Designers' Task for the Municipal Early Childhood Education Centers (EMEIs)}

An EMEI project should start from the assumption that little children do not go to school because of their own choice or wish. Most of the time, they are put apart from the contact with the environments and the people that they know, trust and depend on [26]. When they are moved away from their familiar environments, they need to build their sense or expectations, comprehension and love for life, based on the environment, space, colors, materials and furniture in the EMEIs [23, 24, 26].

So, to project healthy buildings and places, that are inviting and challenging for little children [10], implicates in: (a) question every choice or decision and their impact on children's well-being; (b) avoid that places and buildings are opposed to the ones experienced by the children; (c) search for the best possible result with the limited resources available. It means to say "no" to everything that reduces or excludes the spirit of childhood, keeping in mind that the perception of objects for a little child is not gestaltic nor configurational, but a non-differential reality, that is inaccurate and mingles the limits between objective and subjective, in a reality that is filled with an emotional flow of affections. Yet for the child, such reality is not as chaotic as it may seem for an adult, the same way "a dream is not chaotic for the one who dreams in the moment he is dreaming" [26].

The built environment of EMEIs should serve as an interface of a field of search for co-production relations, established by the little children, their immediate surroundings and the different subjacent spaces of these relationships, such as: spaces between-objects-and-people, affective space, space of our actions, postural space, mental space, games space [23]. It should operate as an agent that invites educators and little children to organize spaces for wandering, deriving and dreaming actions in each context [23]; as a vital surrounding or projection that involves the child, a landscape laboratory [23] or space-time created by the rhythm of actions and the dialogue between the experience of space and objects. Each EMEI should be conceived as an interface that is made of welcoming environments, challenging and stimulating little children's expression, where they will grow, and that will also be influenced by them. These environments should be seen as "game boards" that invite little children to explore their possibilities and produce actions and feel emotions as they learn, transform, find and symbolize [27].

\section{EMEI Colônia Z3}

As an attempt to connect knowledge related to a socio-technical approach (qualitative and subjective) and an assessment of the level of thermal 
comfort-more quantitative and objective - at an EMEI with an FNDE standardized project Type "C", to be built in the Brazilian Bioclimatic Zone 2, we chose the EMEI Colônia Z3, a fishermen village in Pelotas, RS, Brazil (Figs. 1 and 2). It is in a rectangular lot of $35 \times 45$ meters and maximum declivity of $3 \%$. FNDE's

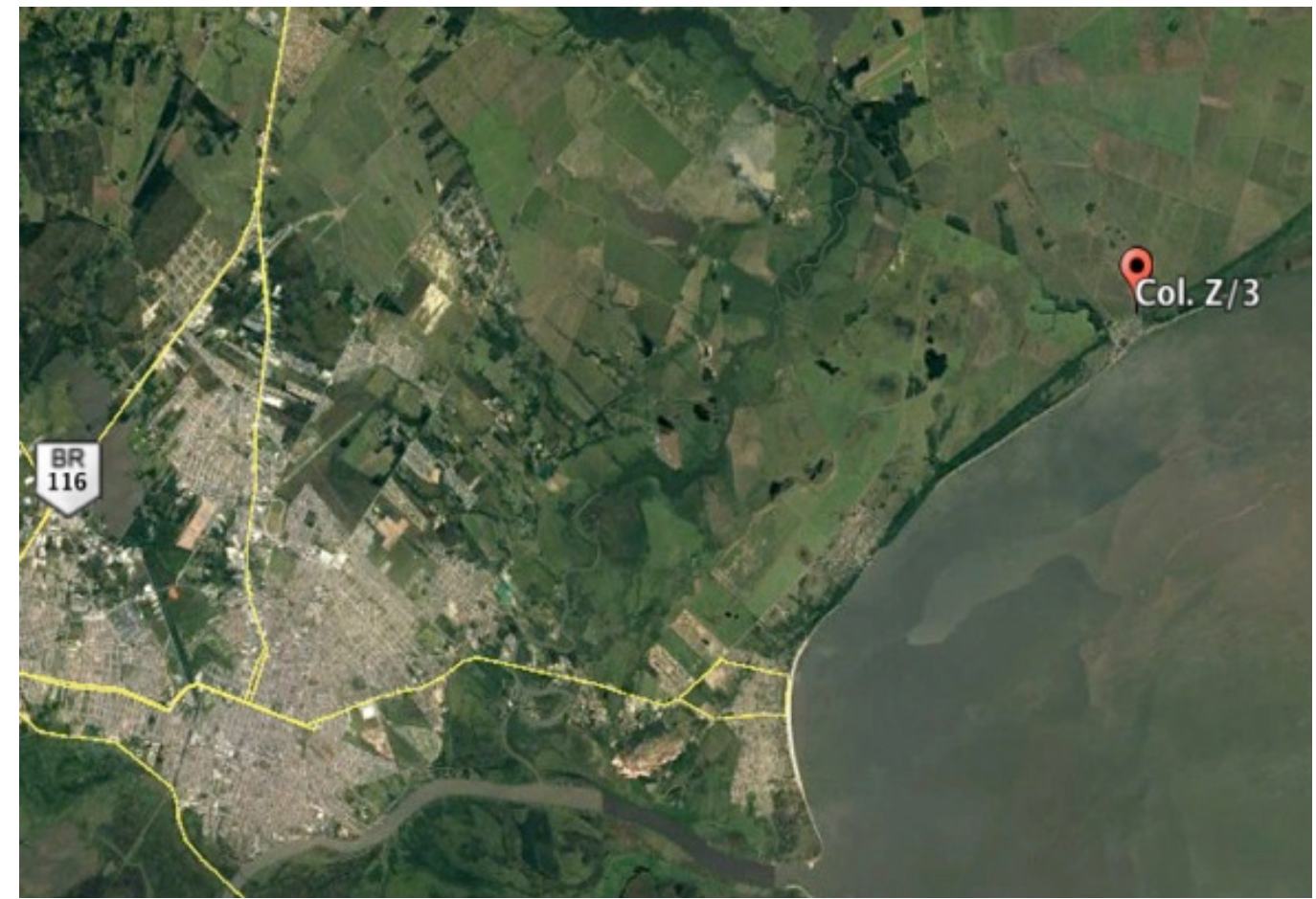

Fig. 1 Location of Colônia Z3.

Source: edited by authors on Google Earth map.

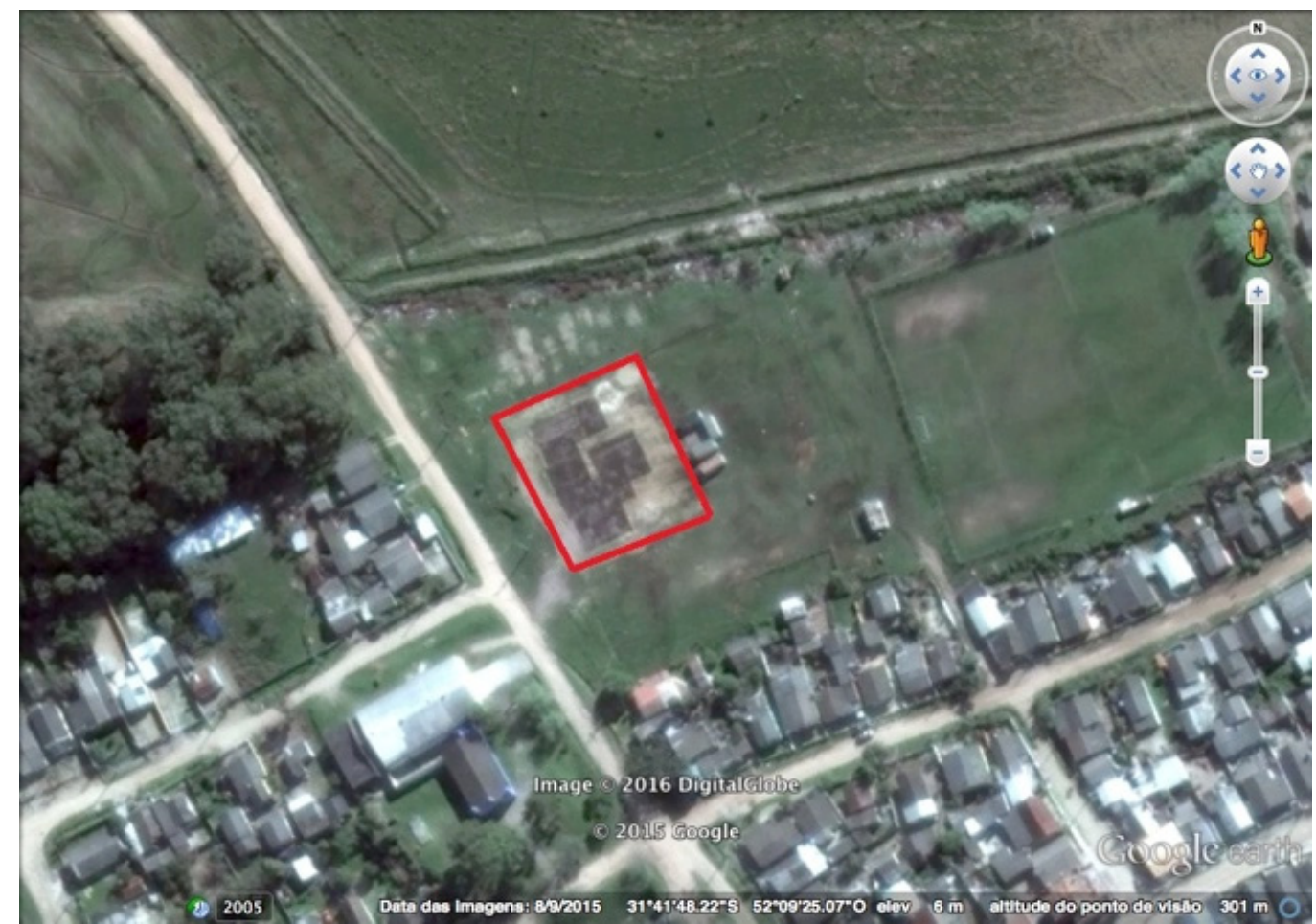

Fig. 2 EMEI Colônia Z3 Lot.

Source: edited by authors on Googleearth map. 
standard projects for pro-childhood EMEIs were initially conceived as a conventional construction system-reinforced concrete structure, walls with 8-hole ceramic brick, double-face plaster, roof with ceramic tiles and ceiling with plasterboard. Because of the delays due to the difficulties with legalization and bidding, they have been adapted by FNDE, in order to use the Wall System developed by MVC Componentes Plásticos Ltda.-foundations in reinforced radier concrete, structural walls composed of PVC profiles filled with self-compacting concrete, yard covered with metallic profile " $\mathrm{H}$ " structure; internal partitions with panels of EPS (expanded polystyrene) and plasterboard and finishings in reinforced plastic, roof with cement tiles and ceiling with plasterboard panels with finishings in reinforced plastic and yard covered with metallic structure and trusses and metallic thermoacoustic tiles. Evaluation also considered the original conception of standard projects Type "C", to compare both performances.

The pattern design Type "C" can receive up to 120 children from 0 to 6 years of age in two shifts or 60 children in full-time. The Memorial [28] text goes against common sense when it states that its conception which is closed, inflexible and indiscriminately the same for the whole national territory, considers the environmental, geographical, climatic and demographic "great diversity", as well as each region's socio-economic resources, cultural contexts, physical, psychological, intellectual, social and development needs of a generic naturalized little child. It does not mention pedagogical practices and the naturalization of the comprehension of "child" becomes more evident when it states that the design's main goal is to attend to its main user, the little child.

Among the criteria to ensure users' comfort, health and safety, it indicates: easy access between blocks, physical safety that restrains access of unaccompanied children to areas like kitchen, laundry, water castle, central gas, light and telephone; circulation between continuous floor blocks without steps, ramps or joints; environments for integration and living together for children of different ages-yards, solariums and external areas; equipped dimensioned for little children. Such criteria are independent of construction techniques and materials. The description of implementation guidelines strengthens the lack of relation between intentions and project, such as: adequacy of the building to environmental guidelines and regional climate, searching for optimal orientation of the building regarding the apparent movement of the sun and the dominant winds (Figs. 3 and 4).

The same things happen regarding functional and aesthetical guidelines: architectural program drawn up for number of users and "operational daily needs" of the day care childhood center, allowing a complete educational experience, adequate to the age; sectorization of the functional sets in blocks distributed to predict the interaction of the little child with the natural environment; volumetry defined by the blocks dimensioning and the type of coverage assures the visual identity of the project and the Pro-Infância Program.

It also states that some elements, like porches, volumes and frames and indoor environments, were thought from the little children's point of view_-again naturalized and homogenized. In what concerns colors and finishings, more generalities: use of playful colors, related to users' age (Figs. 5 and 6). Differently of what is suggested by the Memorial [28], the architectural program disregards specific needs of the users of each EMEI and the balance with climate conditions. It naturalizes local conditions and socio-cultural values and standardizes future users. The choice of construction system privileges execution speed instead of important features like easy maintenance, substitution of components and behavior of the materials used in the several stages. Choosing an unconventional construction system that is not well-known in the region and that has never been used for building EMEIs and is produced by only one company, which owns the property rights, with real 


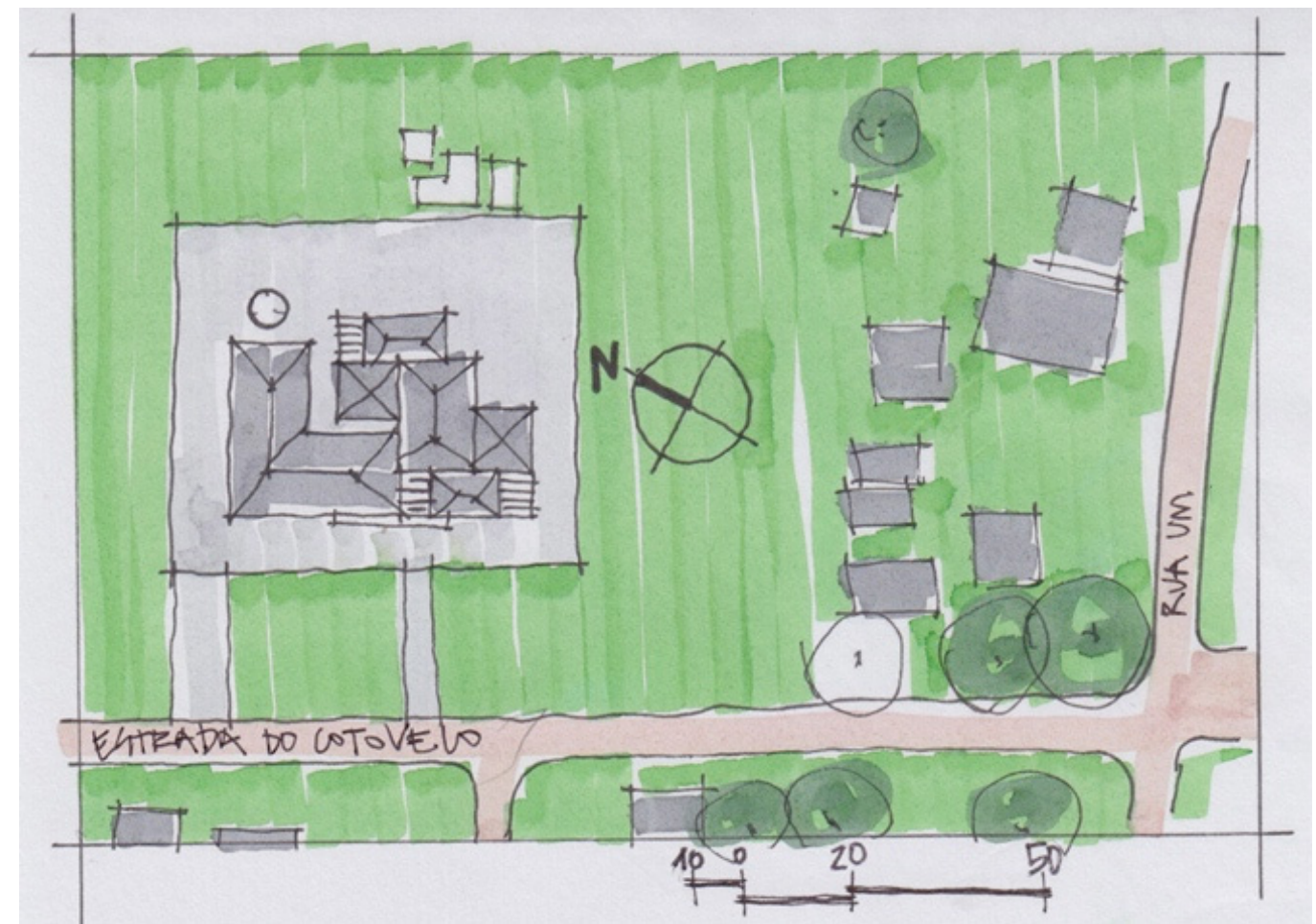

Fig. 3 EMEI Colônia Z3-location.

Source: the authors.

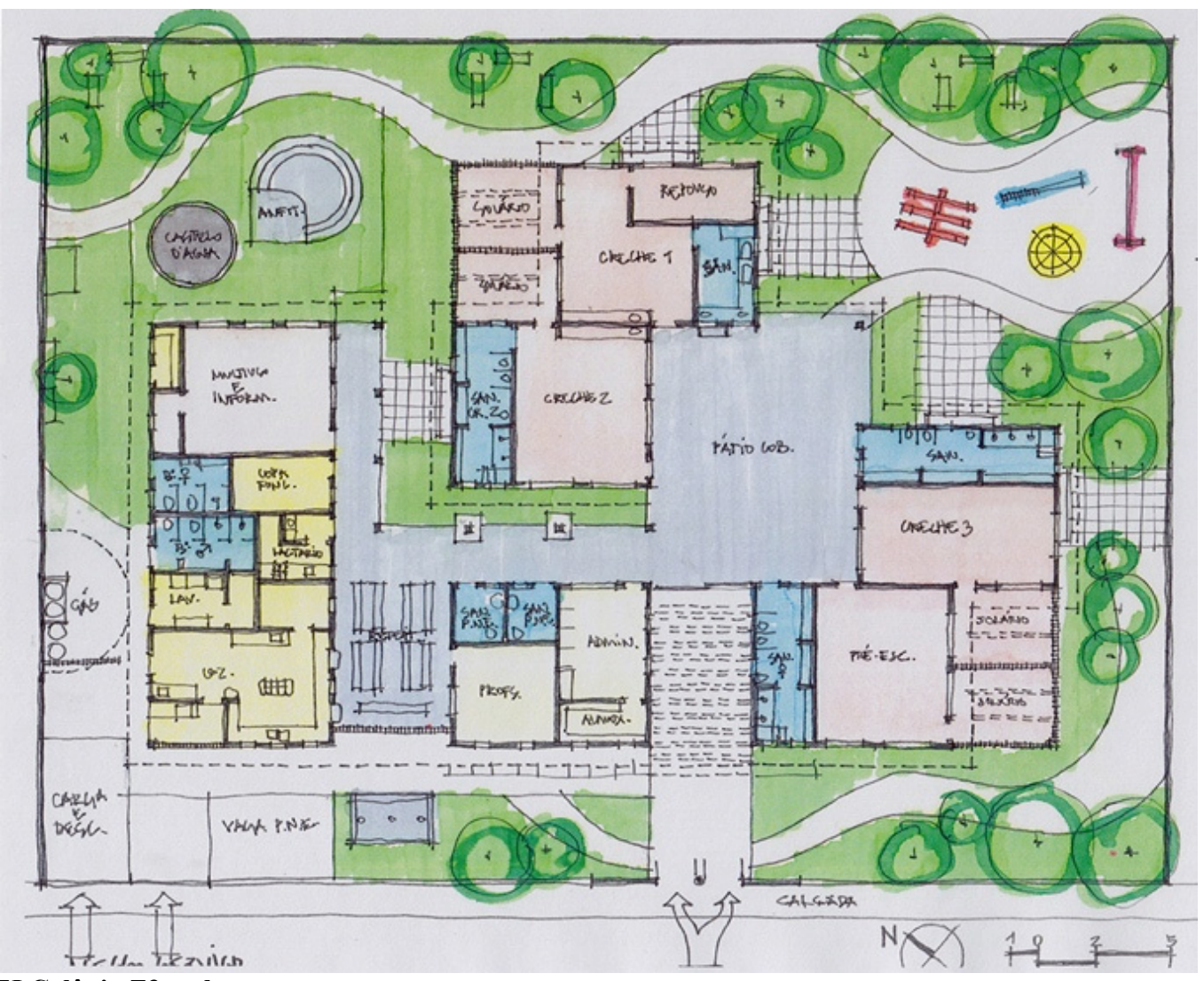

Fig. 4 EMEI Colônia Z3-plan.

Source: the authors. 


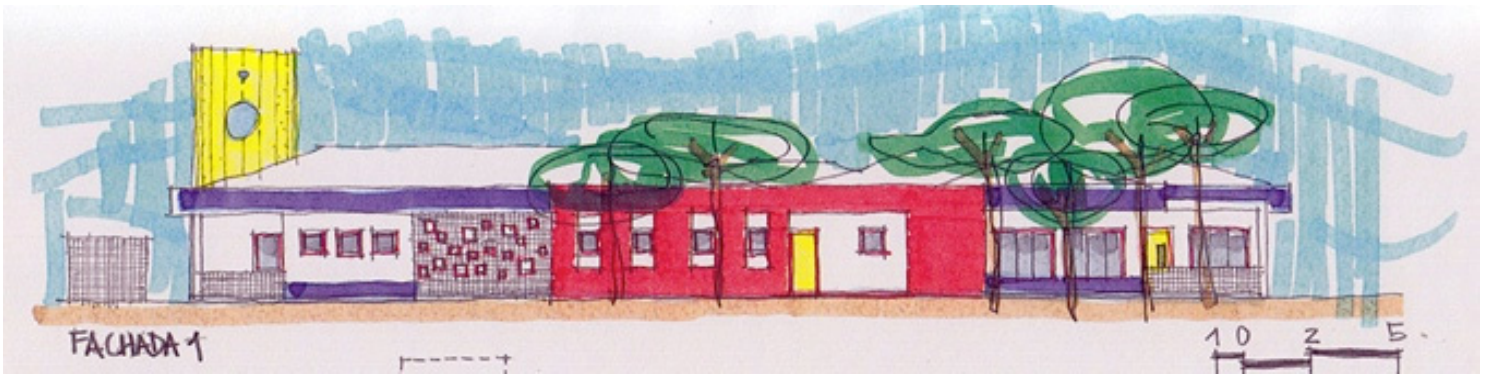

Fig. 5 EMEI Colônia Z3-SW façade.

Source: the authors.

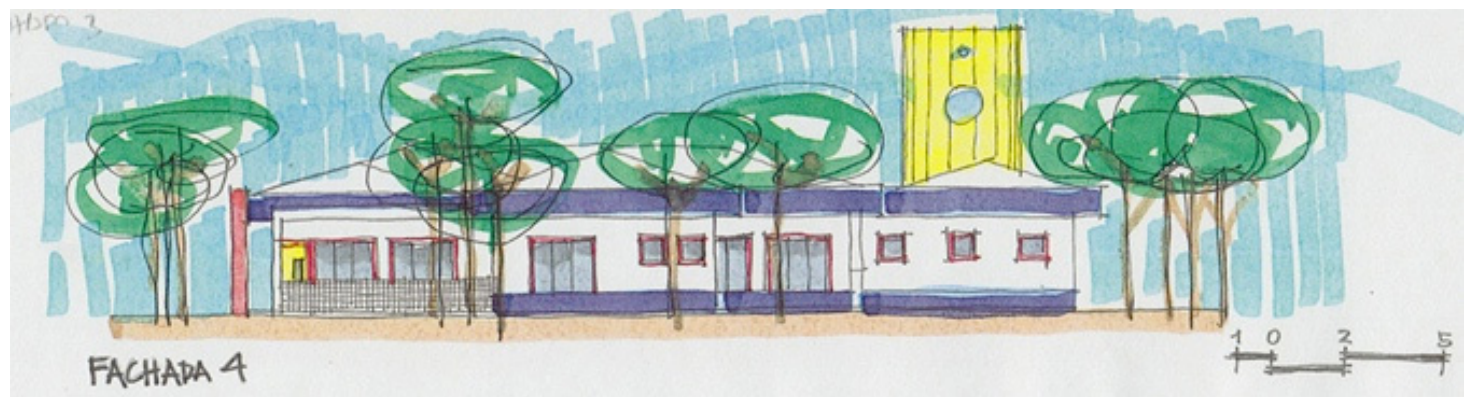

Fig. 6 EMEI Colônia Z3 - NE façade.

Source: the authors.

durability and performance when facing climatic, environmental and usage conditions does not attend the principles of sustainability neither favors identification of the local population with the building.

Transposition to the ground (Figs. 3 and 4) exposes some contradictions with the promises of the Memorial [28]: the blocks of Day Care III and pre-school (SW and SE squares) are a problem in the cold season, and the ensembles of yard-eating place and covered yard-hall-main access make a channel for the dominant wind (NE). Every external window of the blocks designated for children demand external elements of protection from direct sun radiation (brise-soleils, cobogós or rolling shutters). As it already happens at the EMEI Vera Sass [29], the proximity of the covered yard to the four activity rooms may produce excessive noise, making it hard for children to rest [30].

\section{Methodological Strategies}

Even though they have been addressed together during research, predicting a possible and probable unfamiliarity of the readers with the background and practices of the STS studies, the methodological strategies, findings and contributions from qualitative and quantitative approaches and their multiple relations with the EMEI project are hereon presented separately.

The quantitative approach emphasizes the level of thermal comfort in the internal spaces for long-time occupation in the original project and the effects of the optimization measures for the building's thermal performance, by using energy modeling as a research strategy. To assess thermal comfort, the thermodynamic simulation of the EMEI was divided into three stages: modeling, simulation and result analysis, using the two construction systems indicated by FNDE: the MVC system, with wall composed of boards of GFRP (glass-fiber reinforced plastic), plasterboard, extended polystyrene-indicated for the construction of the EMEI Colônia Z3, and the conventional system, using masonry with 8-hole ceramic coated bricks, ceramic tiles and the same ceiling of the MVC system-used in the first constructions of EMEIs of Types " $\mathrm{B}$ " and " $\mathrm{C}$ " and in the standard projects Types 1 and 2. Optimization measures of thermo-energetic performance using 
opaque and transparent closings (in the ceiling) were tested in both systems. The level of thermal comfort at the EMEI Colônia Z3 was assessed through computer simulation using the DesignBuilder software, considering the building as naturally ventilated. As an indicator of level of thermal comfort in indoor environments, we used adaptative comfort by ASHRAE 55 [30]. Besides evaluating the level of thermal comfort of indoor environments, we also analyzed optimization measures of the envelope, aiming to improve conditions of thermal comfort and to insert a mixed system of solar protection.

For modeling and configuration of the EMEI Colônia Z3 to be built in the city of Pelotas, located in the Bioclimatic Zone 2 (ZB2), NBR 15.220-3 [31], the following guidelines and procedures have been adopted:

Since Pelotas does not have climate files yet, it was necessary to use the one available for TMY (typical meteorological years) from Santa Maria/RS (BRA_Santa.Maria.839360_SWERA.epw) [30] which is also in ZB2, with time variations in temperature, humidity, direction and speed of the wind and solar radiation.

Opening hours of the school were defined from 7:30 to $17: 30$.

Observing activities and specific occupation, the long-time occupancy environments were set as "occupied" during the whole time the school is open.

Each one of the EMEI's environments was characterized as a thermal zone.

Configuration of opaque (horizontal and vertical) and transparent closings for both construction systems. (MVC X conventional) (Table 1).

Configuration of usage and occupation conditions considered: (1) the prediction of number of people (adults and children) using each environment; and (2) the different activities they carry out, characterizing each environment's density.

Configuration of the EMEI with natural ventilation was based on the work by Martins et al. [32], using a defined set point for opening windows at $25{ }^{\circ} \mathrm{C}$. If indoor temperature gets to $25^{\circ} \mathrm{C}$ while the outdoors' is lower than $25^{\circ} \mathrm{C}$ and higher than $20^{\circ} \mathrm{C}$, windows must be open, to use natural ventilation.

The schedule for operating windows allows natural ventilation of the environments during the opening days and hours (from Monday to Friday, from 7:30 to 17:30). Internal temperature and cooling set point indicate when they need to be open or not.

The lighting system was configured separately for each thermal zone, considering the density of lighting power installed in each environment. These values have been obtained from data from the electrical project and from the result of sum of the power of each luminaire installed divided by the environment's area.

Simulation analyzed the environments' level of thermal comfort. The indicator of thermal comfort used was adaptative comfort by ASHRAE 55 [30], which considers the users' capacity to adapt to the local microclimatic context in a naturally ventilated environment, by operating the opening and closing of windows and doors.

Intending to improve the level of thermal comfort for the "users" of the EMEI, optimization measures for performance in vertical and horizontal plans have been proposed and tested. Since the roof is the building's enveloping element that receives most of the solar radiation along the year, and because of its importance in defining thermal loads, three proposals have been

Table 1 Construction systems of FNDE's standardized project for EMEI Type "C".

\begin{tabular}{lllll}
\hline EMEI & MVC technology & $\mathrm{U}\left(\mathrm{W} / \mathrm{m}^{2} \mathrm{~K}\right)$ & Conventional technology & $\mathrm{U}\left(\mathrm{W} / \mathrm{m}^{2} \mathrm{~K}\right)$ \\
\hline Walls & $\begin{array}{l}\text { Glass-fiber reinforced plastic, plasterboard, } \\
\text { extended polystyrene and glass-fiber } \\
\text { reinforced plastic }\end{array}$ & 0.55 & $\begin{array}{l}\text { 8-hole ceramic coated bricks } \\
\text { measuring } 19 \times 19 \times 9 \mathrm{~cm}, \text { coated in } \\
\text { both faces }(14 \mathrm{~cm})\end{array}$ & 2.59 \\
\hline Roof/ceiling & $\begin{array}{l}\text { Ceramic tiles, air chamber, plasterboard, } \\
\text { extended polystyrene, and plasterboard }\end{array}$ & 1.32 & $\begin{array}{l}\text { Roof with colonial tiles, air chamber } \\
\text { and precast slab }\end{array}$ & 2.48 \\
\hline
\end{tabular}


tested for improving performance: alteration of thermal transmittance of the roofs using an isolation system of mineral wool (thickness of $0.05 \mathrm{~m}$, density of $20 \mathrm{~kg} / \mathrm{m}^{3}$, thermal conductivity of $0.045 \mathrm{~W} /(\mathrm{m} \cdot \mathrm{K})$ and specific heat of $0.75 \mathrm{~kJ} /(\mathrm{kg} \cdot \mathrm{K}))$ beneath the tiles; alteration of absorptance, changing the ceiling color to white $(\alpha=$ 0.20); and both these proposals together: thermal isolation with mineral wool blanket and painting in white, with the characteristics mentioned above. In the vertical plan, horizontal and mixed (horizontal and vertical) solar shutters have been tested in windows.

\section{Weaving Reflections from the Studies of the EMEIS Colônia Z3 and Vera Sass}

Two reference documents produced by COEDI (National Coordination of Child Education) [10, 33], recognize the child as a subject of the education process and the main user of educational environment, and both recommend to follow an ensemble of "essential guidelines": sustainability - a harmonious relation with the surroundings and use of construction materials and techniques that value regional reserves-universal and inclusive accessibility; harmonious relation between the pedagogical proposals and the built environment-one that is compatible with the physical, psychological, social and intellectual needs of the children regarding volume, environment, spatial, material, color and texture arrangements [10, 34]. Among other things, these documents request and demand that voice should be given to multiple actors, such as children, families, educators, communities, project designers, climate, regional materials, local workers and technicians and contexts.

Despising the recommendations of flexibility that would allow to adjust implementation to specific conditions [9], FNDE's projects followed a wider program that is standardized and architectural sets that prioritize economy, construction rationality and the government's policies. Just like many other school architecture proposals, such projects function more as a symbol of a government policy [35] than as an answer to specific demands of the physical-socio-cultural context of each unit. For the head of COEDI, even though they are not according to the reference documents [10, 34], FNDE's standardized projects represent a new paradigm for building EMEIs, since they allow: to review and update the EMEIs technical specifications; to redefine the educational environment for childhood; to rule and control the conception, construction and usage of EMEIs on a national scale; and to orientate the EMEIs' supply expectations. This is the same opinion of the staff responsible for accession, inclusion and execution of the Pro-Childhood Program in Pelotas.

Once they were vertically implemented, FNDE's standard projects for the Pro-Childhood Program disregarded a lot of the "essential guidelines" recommended by the COEDI $[10,34]$, contradicting the assumption that every knowledge is local or situated, making several actors that have been previously mentioned invisible. The rigour of the program, the implementation, the set, the construction system, the form and the aesthetical standards naturalize environments and discredit local peculiarities as well as communities' cultural values.

In another inversion of values, the choice of the lots was only guided by dimensions and topography. Just like the lot choice and the rigour of the program, the implementation of the blocks happened despite the best orientation, according only to the lots' dimensions. The same way, the EMEI Vera Sass, built in 2014 in the city of Erechim, RS, Brasil, also located in ZB2 and with a standard project Type "C", conventional system and capacity to receive 112 children from 0 to 6 years of age full-time, increases the gap between the manual text and the project's lack of flexibility facing real situations. The municipality found difficulties to adapt the EMEI to receive 140 children from 0 to 4 years of age. To receive the 28 exceeding children, it was necessary to adapt a scheme of sharing space by using activity rooms, library and informatics room 
alternately, for two groups of children - except for the entering, leaving and resting hours. Even though the manual mentions adaptations of the standard project for cold climate - closings for the covered yard, to lower the ceilings of the activities rooms to $2.70 \mathrm{~m}$ and to change the granite floor for a vinyl blankets-municipalities must bear the costs. At EMEI Vera Sass, the covered yard received a wood ceiling and was closed with glass, the internal corridor between service and pedagogical blocks was covered. But the granite floor and the $3.00 \mathrm{~m}$ height to the ceiling were kept in the activities rooms [31]. The POE (post-occupancy evaluation) carried out by Berleze et al. [31] identified the following problems:

(1) Walkthrough analysis: nurseries - problems with natural lighting (wide windows orientated to the west are impaired by the use of blackout curtains or by craft paper for darkening the environment) and with crossed ventilation (since smaller windows turned to the covered yard are closed to reduce noise, especially during the children's resting time), increasing humidity and discomfort; roughness of the concrete floor in the solariums. Covered yard and eating place-problems with excessive noise due to the use of low absorbency materials that are not compatible with eating places (during meals, children are distracted by toys and by other children's activities); activities and dimensions also produce dust and noise. The indiscriminate use of granite floor produces discomfort due to thermal asymmetry;

(2) Survey with teachers: inadequacy of the floor (91\%), undersized resting environments (87\%), inadequacy of the stairs for the showers $(74 \%)$; cold corridors, unprotected during winter (91\%); inadequacy of the floor of the covered yard and the eating place (74\%), inadequate proximity to the eating place $(100 \%)$; uncovered yard-inadequate toys (61\%);

(3) Visual mapping: problems with the size of the activities and resting spaces, inadequacy of the floor, problems of natural ventilation, bad smell, orientation of the solariums that reduces their use to one shift. Regarding the collective environments, teachers reported problems in the covered yard and in the eating place (layout, cold in winter and warm in summer-in the teachers' opinion, the nursery, the covered yard and the eating place are too warm in Summer, noise and bad smell); outdoor areas (pleasant and well-dimensioned). The authors highlight the inadequacy of the project and the building during the cold season, as it does not plan a coverage for the external corridors between blocks, exposing users to the wind and to the rain [31].

Municipalities found difficulties for regulating the lots' registries and with bidding, due to the discrepancy of the budgets for each EMEI. Among the several requests they must fulfill, municipalities that are enabled for these projects have to choose lots with the dimensions and the characteristics that meet the projects and the property domains and nominate an engineer as technical manager. The land regulation process, the elaboration of the underground analysis services and the foundations projects took around 2 years and a huge amount of the municipality's budget. Pelotas Municipality was called to Brasília in the beginning of 2012, to discuss a review of the unitary cost of the EMEIs, an extension of the execution deadline for the works that had not yet started, the adhesion to the "innovative methodologies" program and to speed up the bidding process through an electronic trading for the RPN (National Prices Registry). Among the advantages presented by FNDE [36], there were: a single call with more quality specifications; lower price; construction agility; cleanness of the works and sustainability. In the offices in Brasília, everything has been properly planned-favorable arguments also based in simulations, once the system had never been used in Pelotas, even less in schools. However, in the real contexts of the cities that had followed FNDE's recommendations - option for RPN bidding system and choice for the Wall System for construction-like 
Curitiba, where the company headquarters is located and where performance and durability of the EMEIs in different real conditions and microclimates are still unknown, things did not come up exactly as they were planned, according to the Coordinator of FNDE's CODIN (Infrastructure and Development Coordination).

FNDE concluded the national bidding in November 2013, and Pelotas City Hall has signed new contracts for building 14 new EMEIs with MVC, at the same time as it started the landscaping works and the foundations of the five first ones-Eldorado, Getúlio Vargas, Farroupilha, Z3 and Monte Bonito-as a counterpart, requested by the program. Nonetheless, new difficulties appeared during the works in three EMEIs and were turned into reasons for MVC to delay the installation of the construction sites and start building. The company has never admitted that the delay was due to a negotiation to readjust in $18 \%$ the values that have been contracted, under the claim that the costs (estimated in October, 2012) were outdated. The City agreed to bear the increase with its own budget, but the works continued stagnated up to December, 2014, this time due to the bad weather that would be making it difficult to finish construction sites and to start building. By the end of 2015, at the same time as the City disqualified the company, the newspaper Zero Hora published news informing that MVC would be boarding material for building emergency houses to shelter Syrian refugees in Germany [34].

The same way as other proposals of school architecture and despite the recognition by the COEDI and the richness of the program concerning the yard environments and areas, as we mentioned above, FNDE's standard projects for EMEIs function more as a symbol of a government policy than as an answer to the physical, technical, cultural and socio-environmental demands of the places where they are built. There is no dialogue between the EMEI and the context and environment of Colônia Z3: with the rigor of the set, the services block is in the best orientation, disregarding the children's activities rooms. The example of EMEI Colônia Z3 indicated the discontinuity between what is in the project and what is not there... but should be. Such issues point that nowadays, the infrastructure that is needed to comply with the constitutional precept, the guidelines for children education and the quality of the infrastructure of public institutions for children education are still a serious problem [33].

Regarding quantitative issues, the initial results, previous to optimization, indicated: (1) that the conventional construction system shows better performance than the MVC construction system, even though the level of thermal comfort of long-time occupation environments has been low in both systems; and (2) it is necessary to improve the architectural project. Table 2 shows the level of comfort of conventional and MVC systems, respectively.

While the vertical closings of the EMEI with conventional construction system presented an average level of thermal comfort in long-time occupation environments of about $60 \%$, vertical closing with MVC

Table 2 Results of the optimization simulations for EMEI Z3 - \% of thermal comfort according to ASHRAE 55.

\begin{tabular}{llllllc}
\hline \multirow{2}{*}{ Description of simulations } & \multicolumn{3}{c}{ Conventional System } & \multicolumn{3}{c}{ MVC System } \\
\cline { 2 - 7 } & Cold (\%) & Heat (\%) & $\begin{array}{l}\text { Comfort } \\
(\%)\end{array}$ & Cold (\%) & Heat (\%) & $\begin{array}{l}\text { Comfort } \\
(\%)\end{array}$ \\
\hline EMEI Z3 & 13.7 & 25.9 & 60.4 & 9.3 & 39.9 & 50.8 \\
case base & 14.2 & 24.8 & 61.0 & 10.5 & 33.5 & 56.1 \\
EMEI Z3 + Coverage with 0.2 absorpt. & 13.5 & 25.7 & 60.8 & 8.8 & 39.4 & 51.9 \\
EMEI Z3 + Coverage with isolation & 13.8 & 25.0 & 61.2 & 9.4 & 35.5 & 55.1 \\
EMEI Z3 + Coverage with 0.2 absorpt. + isolation & 15.2 & 22.8 & 62.0 & 12.2 & 21.4 & 66.4 \\
EMEI Z3 + Coverage with 0.2 absorpt. + isolation + brise & & & & &
\end{tabular}


System presented about $50 \%$. When considering only occupied hours (from 7:00 to 17:30), the difference was more than 300 hours or about 10 days a year of thermal discomfort due to heat than the best configuration.

While heat thermal discomfort was at about $40 \%$ of the hours in the year at the EMEI with MVC System, it dropped to almost $25 \%$ of the hours in the year in the conventional system, with coated ceramic masonry. During winter, indoor environments with vertical sealings of coated ceramic brick are approximately $6 \%$ colder than the ones with plastic board sealing by MVC System. Placing results in a linear way, it is possible to consider that in the MVC System, there was one month more of discomfort due to heat, compared to traditional system. These first results point to a need for optimization measures for thermal performance of the buildings, aiming to improve the level of thermal comfort of the indoor long-time occupancy environments. Even though the envelope of the MVC System presents more thermal isolation, heat gains from the vertical and horizontal sealings, added to the absence of internal thermal mass, result into more discomfort due to heat. As for the conventional system, it is possible to notice a constant performance, with little variation: the building with the painted ceiling obtained a level of thermal comfort of $61.1 \%$, while thermal isolation corresponded to $60.8 \%$. Together, painting and isolation of the ceiling represented $61.2 \%$. Finally, painting and isolation with brises led to a thermal comfort level of $62.0 \%$.

In order to optimize the level of thermal comfort of EMEI Colônia Z3 in both construction systems (MVC and conventional systems), two possible measures for thermal comfort in long-time occupation environments have been tested. The first one, regarding the horizontal plan, with alteration of the absorptance and isolation of the ceiling; and the second one, regarding the vertical plan, by inserting mixed solar protectors. At first, painting the ceiling in white was tested. Considering both construction systems, the level of thermal comfort in the long-time occupation environments increased around $1 \%$ in the conventional system and $4 \%$ in the MVC one. In the specific case of thermal isolation of the ceiling, an increase of $1 \%$ was observed in the hours of thermal comfort inside the building, which means an addition of 30 hours in the year. The simulation with a combination of both solutions and increasing thermal isolation of the roof by painting the tiles in white resulted into an improvement of $5 \%$ in the MVC System, or an addition of 150 hours of 15 days of thermal comfort along the year, considering the school's opening hours. For the conventional system, with wall in ceramic masonry, improvement was at about $1 \%$ or 30 hours. The inclusion of protectors from the Sun increased thermal comfort in the MVC System by $15 \%$, or an addition on 450 hours or 45 days of thermal comfort for the users of these environments, which characterizes a significant change. In the conventional system, the alteration was only $1 \%$.

\section{Final Considerations}

Firstly, it is necessary to reassert the influence of FNDE's pattern designs in the comprehension of the infrastructure needed for children education, without forgetting that its conception and unilateral adoption disregarded important points like dialogue and the relation of co-production with little children, educators, families and communities. Also, it conceives "users" and EMEIs as separate things and suggests the existence of an essential usage, which is naturalized and deductible from the EMEI itself, independently of who its "users" are and how these "users" are and that EMEIs interact. How are "users" defined and by whom? How do project designers think the users? Who speaks for users and how [37]? These questions remain open. The arguments in the Manual text indicate an old-fashioned conception of "users", as generic, passive and adaptable beings. The projects "script" configured future "users" of EMEIs as a homogeneous category and considered issues like gender, age, socio-economic and ethnical differences as irrelevant 
[37].

Simulations, on the other hand, showed that the alteration proposed had a stronger impact over the MVC system, with worse thermal performance, approximating the level of thermal comfort of the two alternatives for construction systems. The test with two solutions for optimizing the EMEI resulted in $62 \%$ of the opening hours with thermal comfort in the conventional technology; while in the MVC, $66.4 \%$. Optimization did not achieve the $80 \%$ recommended by the RTQ-C for naturally ventilated environments, neither the $85 \%$ recommended by the level " $\mathrm{C}$ " of ISO 7730 [35]. In future works, analysis shall consider the influence of the vegetation in the thermal comfort of the building in controlling direct solar radiation as a project strategy, which is important for producing healthy, inviting and challenging places for little children $[10,36]$. It is important to highlight that the project with MVC technology presented low thermal performance at first and after optimization measures, it showed the highest levels among the simulated proposals. Another aspect to consider is the need to review the architectural project, once the best performance of the conventional system is still very low-around $65 \%$, even when all improvements are included. It is recommended that form and configuration of the project are reviewed, taking advantage of the façades with north and south orientation and placing the biggest windows in the north one, to make it easier to control direct solar radiation and dominant winds (NE) in the warm seasons. Simulation allowed to verify that the MVC construction system, with the worst performance, may be the best choice if the project is corrected, by incorporating eaves or porches that protect the walls, windows and doors from direct solar radiation. With simulated project corrections and adjustments, comfort thermal increased from $50 \%$ to $66 \%$, corresponding to 45 days more of thermal comfort for users. This study highlighted the importance of the adequate orientation and construction system in architecture projects.
Results indicate that it is not enough to only consider the designers' point of view nor to improve isolation of the envelope, if direct solar radiation is not controlled.

\section{Acknowledgments}

The authors thank Brazil's Coordenação de Aperfeiçoamento de Pessoal de Nivel Superior (Capes-Coordination for the Improvement of Higher Education Personnel), Conselho Nacional de Desenvolvimento Científico e Tecnológico (CNPq-National Council for Scientific and Technological Development) and Fundação de Amparo à Pesquisa do Estado do Rio Grande do Sul (FAPERGS-Rio Grande do Sul State's Research Support Foundation) for the financial support.

\section{References}

[1] Haraway, D., Localizados, S., Pagu, C. 1995. "Situating Technoscience: An Inquiry into Spatialities, 2000.” $L A W$ J. 2: 7-11. Accessed May 5, 2015. http://www.comp.lancs.ac.uk/sociology/papers/Law-MolSituating-Technoscience.pdf.

[2] Cetina, K. K. 2001. "Postsocial Relations: Theorizing Society in a Postsocial Environment." In Handbook of Social Theory, edited by Ritzer, G., and Smart, B. London: Sage, 520-37.

[3] Oudshoorn, N., and Pinch, T. 2005. "Introduction: How Users and Non-users Matter." In How Users Matter-The Co-construction of Users and Technology, edited by Oudshoorn, N., and Pinch, T. Cambridge: The MIT Press, 1-25.

[4] Farías, I. 2010. "Introduction." In Urban Assemblages How Actor-Network Theory Changes Urban Studies, edited by Farías, I., and Bender, T. New York: Routledge, $1-21$.

[5] Guggenheim, M. 2010. "Mutable Immobiles: Building Conversion as a Problem of Quasi-Technologies." In Urban Assemblages How Actor-Network Theory Changes Urban Studies, edited by Farías, I., and Bender, T. New York: Routledge, 161-78.

[6] Bijker, W., and Pinch, T. 2012. "Preface to the Anniversary Edition." In The Osicla Construction of Technological Systems, edited by Bijker, W., Hughes, T., and Pinch, T. Cambridge: The MIT Press, 11-34.

[7] Flores, M. L., and Albuquerque, S., ed. 2015. Implementação do Proinfância no Rio Grande do Sul: Perspectivas Politicas e Pedagógicas. Porto Alegre: EdiPUCRS. (in Portuguese) 
[8] Kowaltowski, D. 2011. Arquitetura Escolar: O Projeto do Ambiente de Ensino. São Paulo: Oficina de Textos. (in Portuguese)

[9] Faria, B. G. 2010. Conversa da Escola Com a Cidade: Do Espaço Escolar ao Território Educativo. Rio de Janeiro: UFRJ. (in Portuguese)

[10] Morin, E. 2003. A Cabeça Bem Feita-Repensar a Reforma, Reformar o Pensamento. 8th ed. Rio de Janeiro, Bertrand. (in Portuguese)

[11] Morin, E. A Cabeça Bem Feita - Repensar a reforma, reformar o pensamento. Rio de Janeiro, Bertrand, $8^{\text {a }}$ Ed., 2003.

[12] Latour, B. 2000. Ciência em Ação. São Paulo: Editora UNESP. (in Portuguese)

[13] Latour, B. 2005. Reassembling the Social: An Introduction to ANT. New York: Oxford University Press.

[14] Maturana, H. 2001. Cognição, Ciência e Vida Cotidiana. Belo Horizonte: Editora UFMG. (in Portuguese)

[15] Farías, I., and Bender, T., ed. Urban Assemblages How Actor-Network TheoryChanges Urban Studies. New York: Routledge.

[16] Latour, B. 2008. "Como Falar do Corpo? A Dimensão Normativa dos Estudos Sobre a Ciência." In Objectos Impuros-Experiências em Estudos Sobre a Ciência, edited by Nunes, J. A., and Roque, R. Porto: Edicões Afrontamento, 39-61.

[17] Hoyuelos, A. 2005. "Estrategias del Juego en Laescuela." In Territorios de la Infância: Diálogos Entre Arquitectura y Pedagogia, edited by Cabanellas, I., and Eslava, C. Porto: Editorial Graó, 137-42. (in Portuguese)

[18] Nunes, M. F. R. 2005. Proinfância e as Estratégias Municipais de Atendimento a Crianças de 0 a 6 anos. Rio de Janeiro: Maria Fernanda Rezende Nunes. (in Portuguese)

[19] Oudshoorn, N., and Pinch, T. 2005. How Users Matter-The Co-construction of Users and Technology. Cambridge: The MIT Press, 2005.

[20] Sarmento, M. J. 2007. "Visibilidade Social e Estudo da Infância." In Infância (in) Visivel, edited by Vasconcellos, V. M. R., and Sarmento, M. J. Araraquara/SP: Junqueira \& Martins, 25-49. (in Portuguese)

[21] Cabanellas, I., and Eslava, C. 2005. Territorios de la Infância: Diálogos Entre Arquitectura y Pedagogia. Barcelona: Editorial Graó. (in Portuguese)

[22] Vasconcellos, V. M. R. 2007. "Apresentação: Infâncias e Crianças Visíveis." In Infância (in) Visível, edited by Vasconcellos, V. M. R., and Sarmento, M. J. Araraquara/SP: Junqueira \& Martins, 7-23. (in Portuguese)

[23] Goulart de Faria, A. B. 2012. Conversa da Escola com a Cidade do Espaço Escolar ao Território Educativo. Rio de Janeiro: Universidade Federal do Rio de Janeiro. (in Portuguese)
[24] Olds, A. 2001. Child Care Design Guide. New York: McGraw-Hill.

[25] Lima. M. S. 1989. A Cidade e a Criança. São Paulo: Nobel. (in Portuguese)

[26] Carballo, I., Eslava, C., and Fornasa, W. 2005. Territorios de la Infância: Diálogos entre Arquitectura y Pedagogia. Porto: Editorial GRAÓ, 31. (in Spanish)

[27] Polonio, R. 2005. "Barcelona: La Construcción de lo Social." In Territorios de la Infância: Diálogos Entre Arquitectura y Pedagogia, edited by Cabanellas, I., and Eslava, C. Porto: Editorial GRAÓ, 51-5). (in Portuguese)

[28] FNDE-Fundo Nacional de Desenvolvimento da Educação. 2013. Memorial Projeto Proinfância. Brasilia: FNDE. Accessed February 18, 2017. http://www.fnde.gov.br/programas/proinfancia/item/5062. (in Portuguese)

[29] Berleze, A., Tsutsumi, E., Azevedo, G., Modler, N., and Linczuk, V. 2016. Avaliação de Desempenho Ambiental da Escola Municipal de Educação Infantil Vera Beatriz Sass-Erechim/RS. Erechim: UFRJ/UFFS. (in Portuguese)

[30] ASHRAE (American Society of Heating, Refrigerating and Airconditioning Engineers). 2010. Standard 55: Thermal Environmental Conditions for Human Occupancy. Atlanta: ASHRAE.

[31] Martins, V., et al. 2011. O Lugar doPátio Escolar no Sistema de Espaços Livres: uso, Forma e Apropriação (The Place of the School Yard in the Free Spaces System: Usage, Form and Appropriation), edited by edited by Azevedo, G., Rheingantz, P., and Tângari, V. Rio de Janeiro: Universidade Federal do Rio de Janeiro, 121-44. (in Portuguese)

[32] Martins, D. J., Rau, S. L., Reckziegel, S., Ferrugem, A. P., and Silva, A. C. S. B. 2009. "Ensaio Sobre a Utilização da Automação de Aberturas na Simulação do Desempenho Térmico de Edificações.” Presented at X ENCAC. Anais do Evento. Natal.

[33] Brasil, Ministério da Educação. 2010. Projeto de Lei $n^{o}$ 8.035/2010-Plano Nacional de Educação. Brasília: Congresso Nacional, Brasília: Centro de Documentação e Informação-Edições da Câmara. Accessed February 20, 2017. http://unb2.unb.br/administracao/decanatos/dex/ formularios/Documentos\%20normativos/DEX/projeto_de lei_do_plano_nacional_de_educao_pne_2011_2020.pdf.

[34] FNDE (Fundo Nacional de Desenvolvimento da Educação). n.d. Vantagens do novo Método (Advantages of the New Method). Brasília: FNDE. Accessed February 18, 2017. http://www.fnde.gov.br/programas/proinfancia/ proinfancia-reformulacao/proinfancia-reformulacao-meto dologia-inovadora-para-convencional.

[35] Cf. Zero Hora. 2015. “Abrigopara Refugiados (Shelter for Refugees).” Zero Hora, December 07, 2015, 15. (in 


\section{Care Childhood Center in Colônia Z3, Pelotas/RS, Brazil}

Spanish)

[36] Oudshoorn, N., and Pinch, T. 2005. "Introduction: How Users and Non-users Matter." In How Users Matter-The Co-construction of Users and Technology, edited by Oudshoorn, N., and Pinch, T. Cambridge: The MIT Press, $1-25$.
[37] International Organization for Standardization. 2005. ISO 7730: Ergonomics of the Thermal Environment-Analytical Determination and Interpretation of Thermal Comfort using Calculation of $P M V$ and PPD Indices and Local Thermal Comfort Criteria. Geneve: ISO. 